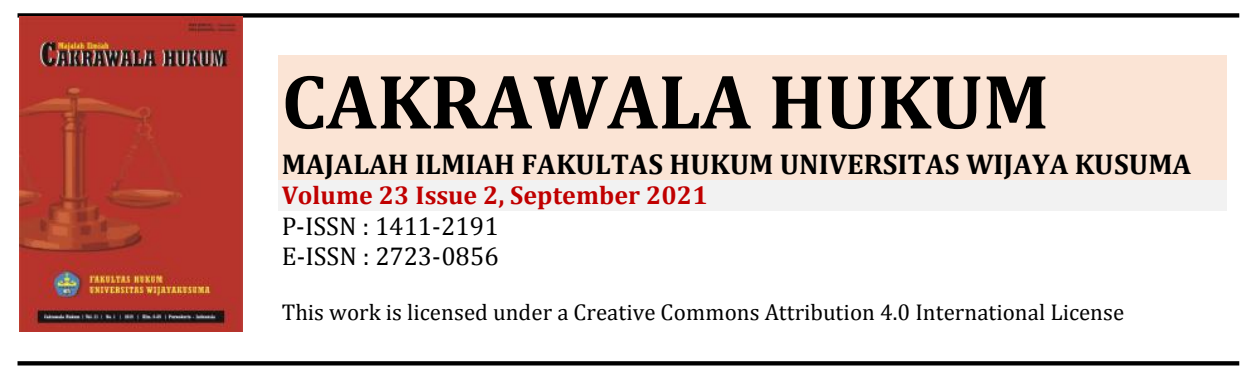

\title{
Pelaksanaan Pengarsipan Akta Kelahiran
}

\author{
Eistetika Sari; Rahayu Subekti.
}

Fakultas Hukum, Universitas Sebelas Maret, Surakarta, Indonesia.

\section{Cooresponding author : rahayusubekti0211@staff.uns.ac.id}

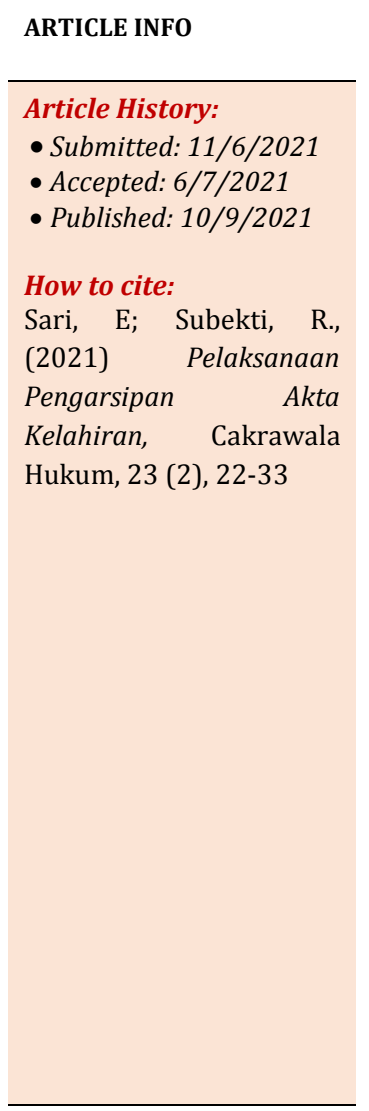

\section{ABSTRACT}

This research aims to determine the implementation of archiving birth certificates at the Department Population and Civil Registration of Sukoharjo Regency, and obstacles and solutions for the Department of Population and Civil Registration of Sukoharjo Regency in the implementation of archiving birth certificates. This research is a descriptive juridical empirical legal research were carried out by interview, observation, and document study, with qualitative data analysis techniques. The approach uses a qualitative approach with primary and secondary data source. The author concludes that Department of Population and Civil Registration of Sukoharjo Regency in carrying out birth certificate archiving has not run optimally. Due to a change in the system from using digital archives to conventional archives. Each of digital and conventional archiving has obstacles and solutions to overcome.

Keywords : Archiving, Birth Certificate.

Abstrak. Penelitian ini bertujuan untuk mengetahui pelaksanaan pengarsipan akta kelahiran di Dinas Kependudukan dan Pencatatan Sipil Kabupaten Sukoharjo serta hambatan dan solusi bagi Dinas Kependudukan dan Pencatatan Sipil Kabupaten Sukoharjo dalam pelaksanaan pengarsipan akta kelahiran. Penelitian ini merupakan penelitian hukum yuridis empiris bersifat deskriptif dengan mengumpulkan data melalui wawancara, observasi dan studi dokumen. Pendekatan menggunakan pendekatan kualitatif dengan sumber data primer dan sekunder, Penulis menyimpulkan bahwa Dinas Kependudukan dan Pencatatan Sipil Kabupaten Sukoharjo dalam melaksanakan pengarsipan akta kelahiran belum optimal. Adanya perubahan sistem dari arsip digital menjadi konvensional. Dalam pengarsipan secara digital maupun konvensional masing-masing memiliki hambatan dan solusi untuk mengatasinya.

Kata kunci : Pengarsipan, Akta Kelahiran.

Copyright (C) 2019 Cakrawala Hukum. All rights reserved.

\section{Pendahuluan}

Setiap organisasi atau instansi baik pemerintah maupun swasta tidak terlepas dari kegiatan administrasi, pelaksanaan kegiatan administrasi di setiap instansi harus berjalan secara efektif dan efisien demi tercapainya tujuan instansi tersebut. Pelaksaaan kegiatan administrasi 
tentu tidak terlepas dari kegiatan kearsipan karena informasi yang di butuhkan dalam pelaksanan kegiatan administrasi dapat ditemukan di dalam sebuah arsip. Pengendalian dokumen hasil pendaftaran penduduk dan pencatatan sipil meliputi penyimpanan, alih media, pemeliharaan, pelayanan dan penyusutan. Alih media Pencatatan Sipil dilakukan dengan cara mengkonversi dokumen format digital. ${ }^{1}$

Seiring dengan perkembangan hukum, pengelolaan dokumen kependudukan dan perkembangan teknologi maka Peraturan Menteri Dalam Negeri Nomor 19 Tahun 2012 tentang Pedoman Pendokumentasian Hasil Pendaftaran Penduduk dan Pencatatan Sipil di Daerah digantikan dengan Peraturan Menteri Dalam Negeri Nomor 104 Tahun 2019 tentang Pendokumentasian Administrasi Kependudukan.

Sistem pengelolaan arsip sangat penting untuk diperhatikan. Apabila arsip tidak dikelola dengan baik maka akan kesulitan dalam hal temu kembali arsip kedepannya. Tidak tepatnya pengelolaan arsip juga akan mengakibatkan permasalahan dalam penemuan kembali arsip, apalagi jika jumlah arsip akta kelahiran sudah mencapai ratusan jutaan file. Sementara file-file yang ada tersebut masih dikelola secara manual, maka diperlukan pengelolaan arsip yang baik dan benar agar arsip yang tersimpan dapat ditemukan kembali dengan cepat dan akurat sehingga dapat digunakan dengan baik oleh masyarakat yang membutuhkan. ${ }^{2}$

Kegiatan administrasi yang dilakukan oleh instansi pemerintah maupun instansi swasta menghasilkan produk administrasi yang sebagian besar berupa arsip dalam bentuk kertas. Arsip konvensional berbahan kertas terbuat dari bahan organik yang dapat mengalami perubahan fisik dan kimiawi seiring dengan lamanya waktu penyimpanan. Banyaknya arsip konvensional yang dihasilkan dari kegiatan administrasi tersebut sering menimbulkan berbagai masalah. ${ }^{3}$

Banyaknya permasalahan yang dihadapi dalam arsip konvensional, maka diperlukan adanya inovasi untuk menunjang organisasi. Salah satu inovasi yang dapat dilakukan adalah dengan pemanfaatan teknologi berbasis komputer yaitu dengan merubah arsip konvensional menjadi arsip elektronik atau disebut kegiatan digitalisasi arsip. Kelebihan yang diperoleh dari digitalisasi arsip ialah arsip yang dibutuhkan cepat ditemukan, menghemat volume ruang dikarenakan tidak membutuhkan ruang yang luas, dapat meningkatkan keamanan dari arsip tersebut, dan mudah dalam melakukan recovery data. ${ }^{4}$

Di Kabupaten Sukoharjo, menurut pendapat Ibnu Haryadi selaku Kepala Seksi Pemanfaatan Data di Bidang Pemanfaatan Data dan Inovasi Pelayanan yang menyatakan bahwa sistem pengelolaan arsip akta kelahiran di Dinas Kependudukan dan Pencatatan Sipil Kabupaten Sukoharjo masih menggunakan sistem kearsipan konvensional yang saat ini belum berjalan sebagaimana yang diharapkan. Selama ini masih dijumpai kendala yang dihadapi seperti penyimpanan arsip akta kelahiran berupa lembaran kertas yang membutuhkan ruang yang banyak dan perawatan yang ekstra. Pada tahun 2017-2018 Dinas Kependudukan dan Pencatatan Sipil Kabupaten Sukoharjo mulai menggunakan sistem kearsipan elektronik (digital) yang dimulai dengan mendigitalisasikan arsip akta kelahiran, namun sistem kearsipan digital tersebut tidak dijalankan lagi

1 Peraturan Menteri Dalam Negeri Nomor 19 Tahun 2012 tentang Pedoman Pendokumentasian Hasil Pendaftaran Penduduk dan Pencatatan Sipil di Daerah.

2 Mukhlis Imam Khambali. "Analisis Penyimpanan Arsip Akta Catatan Sipil untuk Mendukung Tertib Arsip di Kantor Dinas Kependudukan dan Pencatatan Sipil Kota Surabaya”. Jurnal Pendidikan Administrasi Perkantoran. Vol 7. Nomor 3. 2019. Hal 23.

3 Putri Asisul Qowam \& Roro Isyawati Permata Ganggi. “Upaya Penyelamatan Informasi Arsip Vital Melalui Digitalisasi Arsip Register Akta Kelahiran di Dinas Kependudukan dan Pencatatan Sipil Kabupaten Boyolali". Jurnal Ilmu Perpustakaan. Vol 6. Nomor 6. Hal 172.

4 Sovia Rosalin. Manajemen Arsip Dinamis. (Malang: UB Press, 2017). Hal 229. 
karena adanya beberapa kendala salah satunya adalah belum adanya Standar Operasional Prosedur (SOP) yang mengatur terkait digitalisasi arsip pencatatan sipil. ${ }^{5}$

Rumusan masalah dalam penelitian ini yang pertama ialah bagaimana pelaksanaan pengarsipan akta kelahiran di Dinas Kependudukan dan Pencatatan Sipil Kabupaten Sukoharjo, dan yang kedua bagaimana hambatan dan solusi bagi Dinas Kependudukan dan Pencatatan Sipil Kabupaten Sukoharjo dalam pelaksanaan pengarsipan akta kelahiran.

\section{Metode Penelitian}

Penelitian ini menggunakan jenis penelitian yuridis empiris, penulis mengaitkan variabelvariabel sosial yang digali dilapangan untuk mengetahui pelaksanaan pengarsipan akta kelahiran serta hambatan dan solusi bagi Dinas Kependudukan dan Pencatatan Sipil Kabupaten Sukoharjo dalam pelaksanaan pengarsipan akta kelahiran. Pendekatan penelitian ini menggunakan pendekatan kualitatif yang akan menghasilkan data deskriptif, yakni apa yang dinyatakan oleh responden secara tertulis atau lisan dan perilaku nyata. Sifat penelitian menggunakan penelitian deskriptif yang memberikan data dan gambaran secara jelas mengenai pelaksanaan pengarsipan akta kelahiran serta hambatan dan solusi bagi Dinas Kependudukan dan Pencatatan Sipil Kabupaten Sukoharjo dalam pelaksanaan pengarsipan akta kelahiran.

Sumber data penelitian ini ialah data primer dan data sekunder. Sumber data primer dalam penelitian ini adalah wawancara dengan pihak terkait dalam pelaksanaan pengarsipan akta kelahiran di Dinas Kependudukan dan Pencatatan Sipil Kabupaten Sukoharjo dan sumber data sekunder diperoleh dari peraturan perundang-undangan, buku, jurnal hukum, thesis, artikel serta data lain yang diperoleh melalui media internet.

Teknik pengumpulan data yang dilakukan adalah penelitian lapangan dan studi pustaka. Dalam penelitian lapangan, penulis melakukan observasi dan wawancara. Untuk studi pustaka, penulis memperoleh dari berbagai literatur, buku, majalah/ artikel, peraturan perundangundangan, bahan internet, hasil penelitian terkait dan sumber lainnya. Teknik analisis data yang digunakan penulis adalah analisis kualitatif. Data yang diperoleh disusun dan dianalisis untuk ditarik kesimpulannya. Dalam teknik analisis ini terdapat tiga komponen yaitu reduksi data, penyajian data, penarikan kesimpulan dan verifikasi.

\section{Hasil dan Pembahasan}

\section{A. Pengelolaan Arsip Akta Kelahiran di Dinas Kependudukan dan Pencatatan Sipil} Kabupaten Sukoharjo

1. Digitalisasi Arsip Akta Kelahiran

Digitalisasi arsip dilakukan untuk membuat arsip dokumen dalam bentuk digital. Kegiatan digitalisasi arsip di Dinas Kependudukan dan Pencatatan Sipil Kabupaten Sukoharjo dapat di uraikan sebagai berikut:

a. Dasar Hukum atau Pedoman yang digunakan dalam Digitalisasi Arsip Akta Kelahiran

Dasar hukum yang mengatur tentang digitalisasi arsip yaitu Peraturan Menteri Dalam Negeri Nomor 19 Tahun 2012. Dasar hukum atau pedoman berguna agar kegiatan yang dilakukan dapat sesuai dengan standar yang ada, sehingga akan diperoleh keseragaman dan standar dalam proses digitalisasi. Terdapat 4 dasar hukum yang digunakan dalam kegiatan digitalisasi arsip akta kelahiran yaitu Undang-Undang Nomor 24 Tahun 2013, Undang-Undang Nomor 43 Tahun 2009, Peraturan Pemerintah Nomor 40 Tahun 2019, Peraturan Menteri Dalam Negeri Nomor 19 Tahun 2012.

5 Wawancara, 25 Januari 2021. 
Dalam pelaksanaan pengarsipan secara digital Dinas Kependudukan dan Pencatatan Sipil Kabupaten Sukoharjo tidak memiliki SOP (Standar Operasional Prosedur), sehingga kegiatan tersebut berjalan sendirinya sesuai aturan dari Dinas tersebut. ${ }^{6}$ Dalam Peraturan Menteri Dalam Negeri Nomor 19 Tahun 2012 pun tidak menjelaskan secara detail terkait dengan teknis pelaksanaan digitalisasi arsip. Pembuatan pedoman (SOP) diperlukan untuk mengawal dan mempermudah pengoperasian sistem maupun peralatan yang digunakan. Pentingnya suatu SOP dalam pelaksanaan kegiatan digitalisasi agar dapat dilaksanakan dengan sesuai standar. ${ }^{7}$

\section{b. Pendanaan dalam Digitalisasi Arsip Akta kelahiran}

Pendanaan merupakan unsur yang sangat penting dalam kegiatan digitalisasi arsip. Pendanaan ialah suatu anggaran yang dialokasikan untuk mendukung kegiatan digitalisasi tersebut. Pembiayaan pelaksanaan kegiatan pendokumentasian hasil pendaftaran penduduk dan pencatatan sipil di kabupaten/ kota dibebankan pada Anggaran Pendapatan dan Belanja Daerah kabupaten/ kota. ${ }^{8}$ Namun di Dinas Kependudukan dan Pencatatan Sipil Kabupaten Sukoharjo untuk melaksanakan kegiatan digitalisasi arsip pendanaannya bersumber dari DAK (Dana Alokasi Khusus) dari Kementerian Dalam Negeri Republik Indonesia. Anggaran tersebut dialokasikan untuk jangka waktu 1 (satu) tahun. ${ }^{9}$

Anggaran tersebut berguna untuk mendukung kegiatan digitalisasi arsip agar dapat berjalan dengan maksimal. Oleh karena itu, alasan yang mendasari dilakukannya digitalisasi arsip akta kelahiran ini adalah untuk mengoptimalkan penyerapan anggaran DAK (Dana Alokasi Khusus) dari pusat. Oleh karena itu, pendanaan pelaksanaan digitalisasi arsip akta kelahiran tersebut tidak sesuai dengan yang telah dijelaskan dalam Peraturan Menteri Dalam Negeri Nomor 19 Tahun 2012 Pasal 30 Ayat (1).

\section{c. Tujuan Pelaksanaan Digitalisasi Arsip Akta Kelahiran}

Tujuan dari arsip elektronik diantaranya adalah: 1) terciptanya pengelolaan dokumen yang baik; 2) adanya penyimpanan salin fisik dokumen ke dalam media elektronik; 3) menjaga keamanan dari informasi yang terkandung dalam dokumen dari bahaya yang tidak diinginkan, seperti kebakaran, banjir, kehilangan dokumen, dan lain sebagainya; 4) sebagai sarana untuk mempercepat proses pencarian dokumen yang dilakukan secara elektronik; 5) mempercepat tujuan penemuan fisik dokumen; 6) dokumen fisik akan terjaga kelestariannya karena penggunanya semakin jarang menggunakan. ${ }^{10}$

Sesuai dengan tujuan digitalisasi arsip (pelestarian arsip) maka arsip akta kelahiran untuk penerbitan tahun 2000-2013 sudah dilakukan digitalisasi dan disimpan didalam aplikasi digitalisasi arsip yang bernama "PAKCAPIL" (Penataan Arsip Kependudukan dan Pencatatan Sipil). Penyimpanan pada aplikasi tersebut sebagai pengamanan arsip, khususnya arsip register akta kelahiran. Dalam hal terjadi hilangnya register akta catatan sipil atau terjadinya bencana yang mengakibatkan kerusakan/ musnah, yang dibuktikan dengan berita acara dari kepolisian, dapat dilakukan pencetakan register akta pencatatan sipil dimaksud dengan memanfaatkan alih

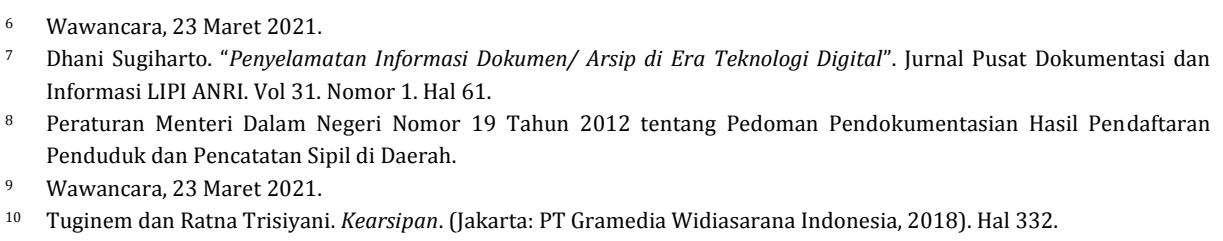

10 Tuginem dan Ratna Trisiyani. Kearsipan. (Jakarta: PT Gramedia Widiasarana Indonesia, 2018). Hal 332. 
media. ${ }^{11}$ Dengan memanfaatkan teknologi informasi sebagai back up dokumen, sehingga dapat membantu mempercepat penemuan kembali dokumen yang diperlukan oleh pengguna.

\section{d. Prosedur Digitalisasi Arsip Akta Kelahiran}

Alih media hasil pencatatan sipil dilakukan dengan cara mengkonversi dokumen ke dalam format digital dan format digitalisasi dapat dilakukan melalui scanning, fotographi digital dan perekaman digital. ${ }^{12}$ Namun prosedur digitalisasi arsip akta kelahiran di Dinas Kependudukan dan Pencatatan Sipil Kabupaten Sukoharjo hanya melalui scanning dan fotographi digital. Arsip yang didigitalisasi di Dinas Kependudukan dan Pencatatan Sipil Kabupaten Sukoharjo adalah arsip akta kelahiran baik register maupun berkas pendukungnya. Akta kelahiran merupakan arsip vital yang tidak dapat tergantikan apabila hilang.

Pelaksana atau petugas dalam kegiatan digitalisasi arsip di Dinas Kependudukan dan Pencatatan Sipil Kabupaten Sukoharjo yaitu Operator di Bidang Pencatatan Sipil dan Pendaftaran Penduduk baik yang sudah Pegawai Negeri Sipil (PNS) maupun Tenaga Harian Lepas (THL). ${ }^{13}$ Sumber Daya Manusia (SDM) sebagai pelaksana kegiatan digitalisasi arsip akta kelahiran harus didukung dengan pelatihan-pelatihan. Pelatihan tersebut bertujuan agar SDM tersebut dapat berkompeten dalam melaksanakan tugasnya.

Pelaksanaan suatu kegiatan pasti membutuhkan suatu sarana dan prasarana. Sarana dan prasarana merupakan alat penunjang keberhasilan dalam suatu kegiatan. Peralatan yang lazim digunakan untuk melakukan alih media arsip adalah berupa seperangkat komputer, baik personal computer (PC) maupun laptop dan scanner. ${ }^{14}$ Berdasarkan hasil penelitian sarana yang digunakan dalam kegiatan digitalisasi arsip akta kelahiran yaitu komputer, scanner atau alat pemindai, handphone dan media penyimpanan. Prasarana yang dimaksud ialah tempat yang digunakan dalam pelaksanaan digitalisasi yaitu di ruang produksi pencatatan sipil dan di ruang pendaftaran penduduk

Sarana dan prasarana dalam kegiatan digitalisasi di Dinas Kependudukan dan Pencatatan Sipil Kabupaten Sukoharjo sudah tersedia, namun sarana yang digunakan tersebut masih milik bidang pendaftaran penduduk dan pencatatan sipil, dan prasarana yang digunakan masih menggunakan tempat di ruang pendaftaran penduduk dan pencatatan sipil.

Berdasarkan hasil wawancara dan observasi penulis, alur pengelolaan digitalisasi arsip akta kelahiran di Dinas Kependudukan dan Pencatatan Sipil Kabupaten Sukoharjo adalah sebagai berikut :

1) Mengambil dokumen arsip akta kelahiran;

2) Log in pada aplikasi "PAKCAPIL" (Penataan Arsip Kependudukan dan Pencatatan Sipil;

3) Melakukan pencarian dengan memasukkan kata kunci berdasarkan kategori yang tersedia (berdasarkan tanggal akta, nomor akta, NIK bayi, nama bayi, tanggal lahir bayi, nama ibu, nama ayah, lokasi arsip, dokumen digital, ataukah berdasarkan status peminjaman dokumen). Pilih salah satu diantara beberapa pilihan tersebut;

4) Untuk akta yang belum terhubung dengan SIAK sebelumnya maka harus menginput data terlebih dahulu dari arsip register akta kelahiran. Kemudian simpan;

5) Melakukan scanning/ pemindaian foto;

6) Simpan gambar.

11 Peraturan Menteri Dalam Negeri Nomor 19 Tahun 2012 tentang Pedoman Pendokumentasian Hasil Pendaftaran Penduduk dan Pencatatan Sipil di Daerah.

12 Peraturan Menteri Dalam Negeri Nomor 19 Tahun 2012 tentang Pedoman Pendokumentasian Hasil Pendaftaran Penduduk dan Pencatatan Sipil di Daerah.

13 Wawancara, 16 Maret 2021.

14 Sutirman. Administrasi Kearsipan di Era Teknologi Informasi. (Yogyakarta: UNY Press, 2019). Hal 112 
Menurut pendapat Muhidin dan Hendri yang menyatakan bahwa tahapan alih media arsip dari tekstual ke media elektronik diantaranya adalah :

1) Menyiapkan surat/ naskah dinas yang akan dialih media

2) Melakukan scanning terhadap naskah/ surat

3) Membuat folder-folder pada komputer, sebagai tempat penyimpanan surat atau naskah dinas yang telah di-scan

4) Membuat hyperlink yaitu menghubungkan antara daftar arsip dengan arsip hasil scan

5) Membuat kelengkapan administrasi alih media, yang terdiri dari surat keputusan tim alih media, berita acara persetujuan alih media, berita acara legalisasi alih media, daftar arsip usul alih media dan daftar arsip alih media. ${ }^{15}$

Berdasarkan hasil wawancara tersebut apabila dikaitkan teori dari Muhidin \& Hendri, maka tahapan pelaksanaan digitalisasi arsip akta kelahiran di Dinas Kependudukan dan Pencatatan Sipil Kabupaten Sukoharjo tidak sesuai dengan pendapat Muhidin \& Hendri. Hal ini dikarenakan dalam pelaksanaannya tidak membuat folder-folder pada komputer, tidak membuat hyperlink, dan belum membuat kelengkapan administrasi alih media.

Penemuan kembali arsip merupakan kegiatan penemuan kembali arsip-arsip yang dibutuhkan untuk kepentingan pelaksanaan kegiatan organisasi. Berdasarkan hasil penelitian, penemuan kembali arsip akta kelahiran digunakan untuk mencetak kutipan kedua akta kelahiran. Penemuan kembali arsip melalui beberapa alur diantaranya adalah : 1) memasukkan kata kunci berdasarkan nama bayi/ NIK/ nomor akta/ tanggal lahir pada aplikasi "PAKCAPIL"; 2) klik "refresh" dan klik nama pemohon yang telah muncul; 3) setelah itu akan muncul hasil arsip digital tersebut; 4) klik pilihan cetak sesuai yang diinginkan; 5) terakhir adalah klik "cetak".

Menurut Muhidin dan Hendri, penemuan kembali arsip digital dapat dilakukan melalui tahapan sebagai berikut:

1) Menyiapkan perangkat komputer, dimana arsip digital tersimpan;

2) Membuka folder daftar arsip yang menyimpan file arsip yang akan dicari;

3) Melakukan pencarian file arsip pada daftar arsip;

4) Membuka file arsip yang sudah ditemukan, melalui fasilitas hyperlink;

5) Melakukan pencetakan (print) arsip. ${ }^{16}$

Tahapan penemuan kembali arsip di Dinas Kependudukan dan Pencatatan Sipil Kabupaten Sukoharjo tidak sesuai dengan pendapat Muhidin \& Hendri. Hal ini karena dalam alur penyimpanannya pun berbeda dengan teori dari Muhidin \& Hendri. Dalam pelaksanaan penemuan kembali arsip menggunakan aplikasi “Pakcapil” lebih mudah untuk dilakukan.

\section{Arsip Konvensional Akta Kelahiran}

a. Pengelolaan Arsip Akta Kelahiran

Pengelolaan arsip akta kelahiran merupakan salah satu pengendalian arsip akta pencatatan sipil secara efektif, efisien dan sistematis yang meliputi penciptaan, penataan, penyimpanan, pemeliharaan dan penyusutan arsip akta kelahiran. Pengelolaan arsip akta kelahiran di Dinas Kependudukan dan Pencatatan Sipil Kabupaten Sukoharjo saat ini kembali dilakukan secara konvensional, kegiatan dalam pengelolaan arsip tersebut dapat diuraikan sebagai berikut :

\footnotetext{
15 Sambas Ali Muhidin dan Hendri Winata. Manajemen Kearsipan untuk Organisasi Bisnis, Sosial Politik dan Kemasyarakatan. (Bandung: Pustaka Setia, 2016). Hal 412.

16 Sambas Ali Muhidin dan Hendri Winata. Manajemen Kearsipan untuk Organisasi Bisnis, Sosial Politik dan Kemasyarakatan. (Bandung: Pustaka Setia, 2016). Hal 180-181.
} 
1) Kegiatan Penciptaan Arsip Akta Kelahiran

Penciptaan arsip akta kelahiran dilakukan berdasarkan pada Undang-Undang Nomor 24 Tahun 2013, Peraturan Presiden Republik Indonesia Nomor 96 Tahun 2018, Peraturan Menteri Dalam Negeri Nomor 104 Tahun 2019, yang dituangkan dalam Standar Operasional Prosedur (SOP) terkait dengan penciptaan akta kelahiran.

Penciptaan arsip akta kelahiran di naungi oleh bidang pelayanan pencatatan sipil, yaitu pada seksi kelahiran yang bertugas menciptakan akta kelahiran. Akta kelahiran terbagi menjadi dua macam yaitu akta kelahiran umum (LU) dan akta kelahiran terlambat pendaftaran (TP). ${ }^{17}$ Penciptaan akta kelahiran di Dinas Kependudukan dan Pencatatan Sipil Kabupaten Sukoharjo dapat melalui tiga jalur yaitu offline ke Dinas Kependudukan dan Pencatatan Sipil, sistem online menggunakan web atau aplikasi AKONE MAK'e dan melalui Kerjasama dengan Rumah Sakit.

Penerbitan akta kelahiran di Dinas Kependudukan dan Pencatatan Sipil Kabupaten Sukoharjo dilakukan dengan cara mengidentifikasi persyaratan yang dikumpulkan oleh pemohon, apabila sudah sesuai dengan persyaratan, kemudian di proses sesuai dengan prosedur yaitu melakukan pengentryan data ke aplikasi SIAK dan pengajuan verifikasi, kemudian kepala seksi dan kepala bidang melakukan verifikasi data. Kepala dinas melakukan penandatanganan elektronik. Selanjutnya di cetak register dan kutipan akta kelahiran. ${ }^{18}$

Perihal tersebut sudah sesuai dengan Standar Operasional Prosedur terkait penciptaan arsip akta kelahiran terlampir dan sesuai dengan Pasal 63 Peraturan Presiden Nomor 96 Tahun 2018 tentang Persyaratan dan Tata Cara Pendaftaran Penduduk dan Pencatatan Sipil. Oleh karena itu, dapat disimpulkan bahwa penerbitan akta kelahiran atau penciptaan arsip akta kelahiran di Dinas Kependudukan dan Pencatatan Sipil Kabupaten Sukoharjo sudah cukup optimal.

\section{2) Kegiatan Penataan Arsip Akta Kelahiran}

Penataan arsip akta kelahiran dapat dilakukan dengan dua cara yaitu dengan pemberkasan dan penyimpanan. Langkah-langkah dalam pemberkasan arsip akta kelahiran yaitu :

a) register, kutipan dan berkas setelah selesai diproses dari ruang produksi dipindahkan ke ruang arsip;

b) antara register, berkas dan kutipan, untuk kutipan disendirikan karena akan diberikan ke pemohon;

c) setiap register dan berkas permohonan akta kelahiran dijadikan satu dengan di steples dan kemudian disusun berdasarkan jenisnya (umum dan terlambat);

d) berkas dan register diurutkan berdasarkan nomor kendali;

e) setelah itu dilakukan penjilidan yang terdiri dari 50 berkas akta dalam satu portapel. ${ }^{19}$

Dalam Peraturan Menteri Dalam Negeri Nomor 104 Tahun 2019 tentang

Pendokumentasian Administrasi Kependudukan tidak diatur secara terperinci terkait prosedur pemberkasan arsip akta pencatatan sipil. Namun, menurut pengamatan dari peneliti bahwa pemberkasan akta kelahiran di Dinas Kependudukan dan Pencatatan Sipil Kabupaten Sukoharjo sudah cukup optimal.

Terkait dengan kegiatan proses penyimpanan arsip akta kelahiran, sistem penyimpanan arsip akta kelahiran menggunakan sistem tanggal sesuai tanggal pembuatan akta yang terdapat di dalam nomor akta. Penyimpanan arsip register dan berkas permohonan dijadikan satu dijilid. Prosedur atau alur penyimpanan arsip akta pencatatan sipil tidak diatur dalam Peraturan Menteri

Wawancara, 23 Maret 2021

Wawancara, 30 Maret 2021

9 Wawancara, 23 Maret 2021. 
Dalam Negeri Nomor 104 Tahun 2019, namun proses atau alur penyimpanan arsip akta kelahiran di Dinas Kependudukan dan Pencatatan Sipil Sukoharjo diantaranya meliputi :

a) arsip yang telah di pilah menurut jenisnya dijadikan satu diurutkan berdasarkan nomor kendali;

b) arsip dijilid menggunakan cover portapel yang berisi 50 berkas untuk setiap portapel nya;

c) apabila ketersediaan portapel belum memadai maka sementara di bendel menggunakan rafia dan ditandai dengan nomor-nomor kendalinya;

d) arsip tersebut disimpan dalam rak dokumen arsip dengan disusun sesuai tahun penerbitan akta kelahiran. ${ }^{20}$

Sarana yang digunakan dalam kegiatan penyimpanan dokumen arsip. Untuk penyimpanan fisik dokumen menggunakan map karton manila tebal/ plastik; kotak berkas/ kotak dokumen; dan filling cabinet/ lemari/ rak dokumen. ${ }^{21}$ Sarana penyimpanan arsip akta kelahiran di Dinas Kependudukan dan Pencatatan Sipil Kabupaten Sukoharjo yang digunakan adalah kotak berkas/ box file dan rak dokumen, tanpa menggunakan map karton manila/ plastik. Perihal tersebut menunjukkan bahwa penyimpanan arsip akta kelahiran di Dinas Kependudukan dan Pencatatan Sipil Kabupaten Sukoharjo belum maksimal, sehingga akan mempersulit dalam penemuan kembali arsip.

\section{3) Kegiatan Pemeliharaan Arsip Akta Kelahiran}

Arsip akta kelahiran yang disimpan perlu dilakukan pemeliharaan supaya arsip tersebut selalu terjaga dan terhindar dari kerusakan dan kehilangan. Pemeliharaan arsip akta kelahiran di Dinas Kependudukan dan Pencatatan Sipil Kabupaten Sukoharjo dilakukan dengan cara menebarkan kapur barus serta dipasang AC untuk menjaga suhu ruang arsip..$^{22}$

Pemeliharaan arsip akta kelahiran di Dinas Kependudukan dan Pencatatan Sipil Kabupaten Sukoharjo terkait dengan ruang penyimpanannya sudah cukup optimal sesuai dengan standar yang diatur dalam Pasal 8 Ayat (1), (2) dan (3) Peraturan Menteri Dalam Negeri Nomor 104 Tahun 2019, kecuali untuk konstruksi standar bangunan kearsipan. Ruang arsip pencatatan sipil yang kurang luas berpengaruh terhadap kurang maksimalnya pemeliharaan fisik dokumen, selain itu juga pemeliharaan terhadap fisik dokumen hanya dilakukan dengan penebaran kapur barus.

\section{4) Kegiatan Penyusutan Arsip Akta Kelahiran}

Kegiatan penyusutan arsip akta kelahiran dilakukan untuk mengurangi kapasitas jumlah arsip yang disimpan, kegiatan penyusutan arsip akta kelahiran dapat dilakukan dengan cara pemindahan dan pemusnahan dokumen arsip. Kegiatan pemindahan arsip akta kelahiran di Dinas Kependudukan dan Pencatatan Sipil Kabupaten Sukoharjo yang sudah pernah dilakukan ialah penyerahan arsip, yaitu penyerahan dari Dinas Kependudukan dan Pencatatan Sipil Sukoharjo kepada Lembaga Arsip Daerah Kabupaten Sukoharjo. Sedangkan untuk pemindahan arsip akta kelahiran dari Kecamatan dan Desa atau UPT Dinas Kependudukan dan Pencatatan Sipil Kabupaten Sukoharjo kepada Dinas Kependudukan dan Pencatatan Sipil Kabupaten Sukoharjo belum pernah dilakukan. Untuk pemusnahan arsip akta kelahiran belum pernah dilakuan baik register maupun berkas permohonan.

Pelaksanaan kegiatan penyerahan dokumen arsip sudah cukup optimal sesuai dengan Pasal 9 Ayat (4) Peraturan Menteri Dalam Negeri Nomor 104 Tahun 2019. Oleh karena itu, dapat

\footnotetext{
Wawancara, 23 Maret 2021.

21 Peraturan Menteri Dalam Negeri Nomor 104 Tahun 2019 tentang Pendokumentasian Administrasi Kependudukan

Wawancara, 23 Maret 2021.
} 
disimpulkan bahwa penyusutan arsip akta kelahiran masih kurang baik, dikarenakan pemindahan dan pemusnahan arsip akta kelahiran belum pernah dilakukan .

b. Pelaksana Pengelolaan Arsip Akta Kelahiran

Pelaksana pengelolaan arsip berperan penting terhadap kegiatan kearsipan di sebuah instansi. Pengelola arsip di Dinas Kependudukan dan Pencatatan Sipil Kabupaten Sukoharjo masih minim orang yaitu terdiri dari 1 pegawai PNS yang berkompeten di bidang kearsipan dan 1 pegawai baru. Pengembangan sumber daya manusia terdiri atas arsiparis dan sumber daya manusia yang memiliki kompetensi dan profesionalitas di bidang kearsipan. ${ }^{23}$ Hanya saja SDM yang dimiliki Dinas Kependudukan dan Pencatatan Sipil Kabupaten Sukoharjo masih minim.

c. Sarana dan Prasarana Pengelolaan Arsip Akta Kelahiran

Sarana dan prasarana merupakan salah satu faktor penunjang keberhasilan tertib pendokumentasian administrasi kependudukan. Sarana dan prasarana arsip konvensional di Dinas Kependudukan dan Pencatatan Sipil Kabupaten Sukoharjo masih kurang memadai. ${ }^{24}$

Sarana dan prasarana pengelolaan arsip akta kelahiran apabila di tinjau dari Peraturan Menteri Dalam Negeri Nomor 104 Tahun 2019 tergolong dalam bagian kegiatan penyimpanan fisik dokumen. Kegiatan penyimpanan fisik dokumen menggunakan map karton manila tebal/ plastik, kotak berkas / kotak dokumen, dan filling cabinet/ lemari/ rak dokumen.

Sarana yang digunakan dalam pelaksanaan pengelolaan arsip di Dinas Kependudukan dan Pencatatan Sipil Kabupaten Sukoharjo sudah sesuai dengan Pasal 7 Ayat (4) Peraturan Menteri Dalam Negeri Nomor 104 Tahun 2019, namun masih terkendala oleh prasarana yaitu ruang arsip yang kurang memadai. Dari kendala ruang arsip tersebut, berpengaruh terhadap jumlah ketersediaan rak dokumen, box file dan map karton, sehingga juga menghambat proses pengelolaan arsip tersebut

\section{B. Hambatan dan Solusi Pengelolaan Arsip Akta Kelahiran di Dinas Kependudukan dan Pencatatan Sipil Kabupaten Sukoharjo}

1. Hambatan dan Solusi Digitalisasi Arsip Akta Kelahiran

Setiap kegiatan digitalisasi pasti mengalami suatu hambatan, baik hambatan secara teknis maupun hambatan non teknis. Hambatan digitalisasi arsip akta kelahiran di Dinas Kependudukan dan Pencatatan Sipil Kabupaten Sukoharjo diantaranya adalah :

a. Kurangnya staff bagian kearsipan (arsiparis) dan arsiparis yang ada tidak mempunyai keahlian di bidang teknologi informasi modern.

b. Belum terdapat sarana khusus untuk digitalisasi arsip dan prasarana (ruang arsip) kurang memadai.

c. Koneksi jaringan internet ke aplikasi "PAKCAPIL" melambat, hal ini dikarenakan berbarengan dengan penggunaan aplikasi untuk pelayanan yang lain.

d. Dokumen hasil pemindaian menggunakan scanner tidak maksimal.

e. Dalam pelaksanaan pendigitalisasian arsip terdapat beberapa register akta kelahiran yang sebagian datanya terkosongi sehingga mempersulit dalam proses penginputan.

Solusi yang dapat dilakukan untuk mengatasi hambatan dalam pelaksanaan digitalisasi arsip akta kelahiran diantaranya adalah :

a. Dalam pelaksanaannya ditangani oleh para staff baik Tenaga Harian Lepas (THL) maupun PNS di Bidang Pendaftaran Penduduk dan Bidang Pencatatan Sipil.

23 Undang-Undang Nomor 43 Tahun 2009 tentang Kearsipan.

24 Wawancara, 23 Maret 2021. 
b. Dalam pelaksanaan digitalisasi arsip menggunakan sarana dan prasarana (misal komputer, scanner, ruangan) milik bidang Pendaftaran Penduduk dan Pencatatan Sipil.

c. Mengurangi jumlah pengguna aplikasi, menambah bandwidth koneksi, dan waktu akses aplikasi tidak dilakukan secara bersamaan.

d. Untuk memperoleh hasil dokumen yang cepat dan tepat, pengambilan gambar dokumen arsip menggunakan handphone.

e. Dengan ditemukannya register yang data nya terkosongi ketika dalam proses penginputan maka dilakukan dengan cara mencari berkas permohonan yang sesuai dengan nomor register yang kosong tersebut.

2. Hambatan dan Solusi Arsip Konvensional Akta Kelahiran

Pengelolaan arsip di setiap instansi pasti mengalami hambatan atau kendala dalam pengelolaannya. Hambatan dalam pengelolaan arsip akta kelahiran di Dinas Kependudukan dan Pencatatan Sipil Kabupaten Sukoharjo yaitu :

a. Minimnya petugas arsip yakni satu petugas arsip lama yang berkompeten dan satu petugas baru. Sumber daya manusia yang berkompeten dalam mengelola arsip adalah arsiparis. ${ }^{25}$

b. Ruang penyimpanan arsip yang kurang memadai dan kurang memenuhi standar,

c. Penyimpanan belum maksimal karena keterbatasan rak arsip, sehingga mengakibatkan berkas arsip mudah tercecer.

d. Belum maksimalnya kegiatan penyusutan arsip mengakibatkan tempat penyimpanan semakin penuh.

Solusi yang dapat dilakukan untuk mengatasi hambatan dalam pengelolaan arsip konvensional akta kelahiran diantaranya meliputi :

a. Dalam pengelolaan arsip konvensional, khususnya dalam hal temu kembali arsip dibantu oleh para staff bidang pencatatan sipil.

b. Dalam hal ruang arsip yang kurang memadai, pengelolaan arsip akta kelahiran tetap dilakukan di ruang arsip yang telah ada.

c. Untuk sementara waktu arsip akta kelahiran yang sudah tidak muat disimpan di rak arsip maka diletakkan di meja dan lantai ruang arsip.

Terkait dengan penyusutan arsip akta kelahiran, baru dilakukan adanya penyerahan arsip dari Dinas Kependudukan dan Pencatatan Sipil Sukoharjo kepada Lembaga Arsip Daerah Kabupaten Sukoharjo.

\section{Penutup}

Pelaksanaan pengarsipan akta kelahiran di Dinas Kependudukan dan Pencatatan Sipil Kabupaten Sukoharjo belum berjalan efektif. Sistem pengarsipan ditahun 2017-2018 menggunakan sistem digital, namun saat ini beralih menggunakan sistem pengarsipan konvensional. Digitalisasi arsip tidak dijalankan lagi karena masih ada beberapa hal yang belum mendukung terkait dengan Sumber Daya Manusia (SDM), sarana dan prasarana, pendanaan serta belum dibuatnya Standar Operasional Prosedur (SOP) Digitalisasi Arsip.

Alasan pada saat itu menggunakan sistem digital ialah untuk mengoptimalkan pendanaan Dana Alokasi Khusus (DAK) dari Kemendagri. Mengingat banyaknya kelebihan yang didapat dari penggunaan sistem digital di era modernisasi sekarang ini, maka lebih baik sistem pengarsipan digital dijalankan lagi dengan catatan berupaya untuk mengatasi hambatan dimasa lampau.

\footnotetext{
25 Undang-Undang Nomor 43 Tahun 2009 tentang Kearsipan.
} 
Hambatan dan solusi dalam pengelolaan arsip digital akta kelahiran di Dinas Kependudukan dan Pencatatan Sipil Kabupaten Sukoharjo diantaranya meliputi : a. minimnya arsiparis dan arsiparis yang ada tidak mempunyai keahlian dalam hal teknologi digitalisasi, oleh karena itu dilaksanakan oleh para staff di Bidang Pendaftaran Penduduk dan Bidang Pencatatan Sipil; b. belum adanya sarana khusus digitalisasi arsip dan ruang arsip belum memadai sehingga menggunakan sarana dan prasarana milik bidang Pendaftaran Penduduk dan Pencatatan Sipil; c. koneksi jaringan internet ke aplikasi "PAKCAPIL" tidak stabil maka harus mengurangi jumlah pengguna aplikasi, menambah bandwid koneksi dan waktu akses aplikasi untuk tidak dilakukan secara bersamaan; d. dokumen hasil pemindaian menggunakan scanner tidak maksimal, oleh karena itu lebih disarankan menggunakan handphone agar memperoleh hasil secara cepat dan tepat ; e. ditemukan register yang data nya terkosongi sehingga mempersulit proses penginputan, maka dilakukan dengan cara mencari berkas permohonan yang sesuai dengan nomor register yang kosong tersebut.

Hambatan dan solusi dalam pengelolaan arsip konvensional akta kelahiran diantaranya adalah : a. minimnya petugas arsip sehingga dalam hal temu kembali arsip dibantu oleh staff bidang pencatatan sipil; b. ruang penyimpanan arsip yang kurang memadai dan kurang memenuhi standar, namun pengelolaan arsip tetap dilakukan di ruang arsip yang telah ada; c. penyimpanan arsip belum maksimal, maka sementara arsip yang tidak muat disimpan di rak arsip diletakkan di meja dan lantai ruang arsip; d. belum maksimalnya kegiatan penyusutan arsip sehingga mengakibatkan tempat penyimpanan semakin penuh, untuk saat ini baru dilakukan adanya penyerahan arsip.

\section{Daftar Pustaka}

Buku :

Sambas Ali Muhidin dan Hendri Winata. 2016. Manajemen Kearsipan Untuk Organisasi Bisnis, Sosial Politik dan Kemasyarakatan. Bandung: Pustaka Setia.

Soerjono Soekanto. 2014. Pengantar Penelitian Hukum. Jakarta: Universitas Indonesia Press. . 2010. Pengantar Penelitian Hukum. Jakarta: Universitas Indonesia Press.

Sovia Rosalin. 2017. Manajemen Arsip Dinamis. Malang : UB Press.

Sutirman. 2019. Administrasi Kearsipan Di Era Teknologi Informasi. Yogyakarta: UNY Press.

Tuginem dan Ratna Trisiyani. 2018. Kearsipan. Jakarta: PT Gramedia Widiasarana Indonesia.

\section{Jurnal :}

Dhani Sugiharto. 2012. "Penyelamatan Informasi Dokumen/Arsip di Era Teknologi Digital”. Jurnal Pusat Dokumentasi dan Informasi LIPI ANRI. Volume 31, Nomor 1, 51-64.

Mukhlis Imam Khambali. 2019. "Analisis Penyimpanan Arsip Akta Catatan Sipil Untuk Mendukung Tertib Arsip Di Kantor Dinas Kependudukan Dan Pencatatan Sipil Kota Surabaya”. Jurnal Pendidikan Administrasi Perkantoran (JPAP). Volume 7, Nomor 3.

Putri Asisul Qowam \& Roro Isyawati Permata Ganggi. 2019. “Upaya Penyelamatan Informasi Arsip Vital Melalui Digitalisasi Arsip Register Akta Kelahiran Di Dinas Kependudukan Dan Pencatatan Sipil Kabupaten Boyolali". Jurnal Ilmu Perpustakaan. Volume 6, Nomor 3, 171180.

\section{Peraturan Perundang-Undangan :}

Peraturan Menteri Dalam Negeri Nomor 104 Tahun 2019 tentang Pendokumentasian Administrasi Kependudukan.

Peraturan Menteri Dalam Negeri Nomor 19 Tahun 2012 tentang Pedoman Pendokumentasian 
Hasil Pendaftaran Penduduk dan Pencatatan Sipil di Daerah.

Peraturan Pemerintah Nomor 40 Tahun 2019 tentang Pelaksanaan Undang- Undang Nomor 23

Tahun 2006 juncto Undang-Undang Nomor 24 Tahun 2013 tentang Administrasi Kependudukan.

Peraturan Presiden Nomor 96 Tahun 2018 tentang Persyaratan dan Tata Cara Pendaftaran Penduduk dan Pencatatan Sipil.

Undang-Undang Nomor 23 Tahun 2006 juncto Undang-Undang Nomor 24 Tahun 2013 tentang Administrasi Kependudukan.

Undang-Undang Rebuplik Indonesia Nomor 43 Tahun 2009 tentang Kearsipan. 